\title{
Acute urinary retention and green urine: unusual findings in the emergency department
}

\author{
Flávia Cunha (1) , ${ }^{1}$ Adriana Girão, ${ }^{2}$ José Eduardo Serra, ${ }^{1}$ Rui Pina ${ }^{2}$
}

'Infectious Diseases

Department, Centro Hospitalar e Universitário de Coimbra EPE, Coimbra, Portugal

${ }^{2}$ Internal Medicine Department, Centro Hospitalar e Universitário de Coimbra EPE, Coimbra, Portugal

\section{Correspondence to} Dr Flávia Cunha;

flavia.cunha12@gmail.com

Accepted 3 June 2021

\section{DESCRIPTION}

A 61-year-old man was admitted to the emergency department with a 24-hour history of anuria and abdominal discomfort. He reported a urinary tract infection in the previous month and had started a product purchased from herbalists in Brazil a few days earlier. Abdominal examination revealed hypogastric tenderness and a distended bladder. A urinary catheter was placed and $900 \mathrm{~mL}$ of green urine were drained (figure 1). Blood tests revealed normal renal function, bilirubin and inflammatory markers. Urine analysis revealed normal urine $\mathrm{pH}$ and density (6.0 and 1.015, respectively), normal urobilinogen $(0.2 \mathrm{mg} / \mathrm{dL})$ and absence of nitrites and leucocytes.

It was found that the product contained Atropa belladonna extract and methylthioninium chloride (methylene blue). The patient was discharged from the emergency department, with indication for immediate suspension of the drug and taking tamsulosin $0.4 \mathrm{mg}$ for 7 days. Urine returned to normal after 5 days. Bladder catheter was removed 1 week later, in follow-up consultation.

A. belladonna extract contains the anticholinergic alkaloids atropine, hyoscyamine and scopolamine. Due to its effects, the compounds that contain this

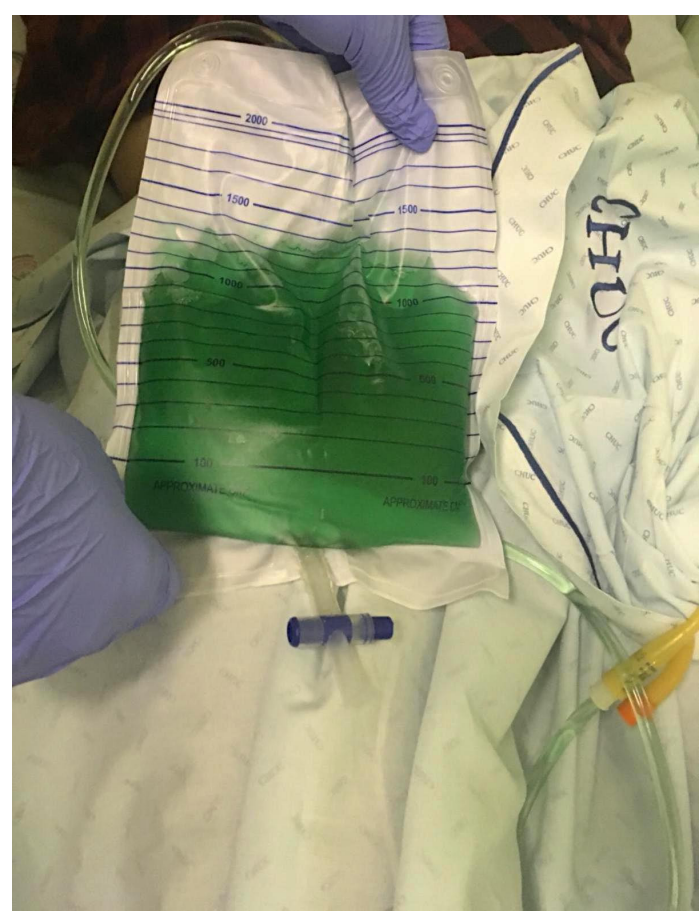

Figure 1 Green urine drained after urinary catheterisation in the emergency department. extract are used to treat cholinergic symptoms of Parkinson's disease and smooth muscle spasms. ${ }^{1}$

Green discolouration of urine is a rare phenomenon, with the most frequent cause being pharmacological: methylene blue and indigo blue dyes are associated with this discolouration ${ }^{2}{ }^{3}$; there are also reports secondary to the administration of propofol. ${ }^{4}$ Other drugs, such as cimetidine, promethazine, amitriptyline, indomethacin and metoclopramide are also associated with this event, as well as infection by Pseudomonas aeruginosa. ${ }^{5}$

In this case, the temporal link between the introduction of the drug and the symptoms allowed us to set a causal relationship for the condition. The anticholinergic effects and green discolouration of the urine are reversible after discontinuation of the drug.

The authors intend to emphasise the importance of taking a complete medical history in the emergency department. The pharmacological history, including the use of products without medical prescription and herbal remedies, which are not always properly explored or valued, may be the key to the diagnosis.

\section{Learning points}

Green discolouration of urine is a rare event It has several causes, such as drugs, dyes or Pseudomonas infection.

- Even in the emergency department, a correct and complete medical history is of major importance.

- Recent pharmacological treatments may be considered in the differential diagnosis of the clinical findings.

Contributors $F C$ and $A G$ were responsible for patient evaluation and manuscript composing. JES and RP were responsible for the scientific review and final approval of the manuscript.

Funding The authors have not declared a specific grant for this research from any funding agency in the public, commercial or not-for-profit sectors.

Competing interests None declared.

Patient consent for publication Obtained.

Provenance and peer review Not commissioned; externally peer reviewed.

ORCID iD

Flávia Cunha http://orcid.org/0000-0002-3202-1688

\section{REFERENCES}

1 Kwakye GF, Jiménez J, Jiménez JA, et al. Atropa belladonna neurotoxicity: implications to neurological disorders. Food Chem Toxicol 2018;116:346-53. 


\section{Images in...}

2 Koratala A, Leghrouz M. Green urine. Clin Case Rep 2017;5:549-50.

3 Stratta P, Barbe MC. Green urine. N Engl J Med Overseas Ed 2008;358:e12.
4 Boshkovska Spaseski M, Spaseski D. Green urine. N Engl J Med 2020;383:e128.

5 Gillett MJ, Burnett JR. Medications and green urine. Intern Med J 2006;36:64-6.

Copyright 2021 BMJ Publishing Group. All rights reserved. For permission to reuse any of this content visit

https://www.bmj.com/company/products-services/rights-and-licensing/permissions/

BMJ Case Report Fellows may re-use this article for personal use and teaching without any further permission.

Become a Fellow of BMJ Case Reports today and you can:

- Submit as many cases as you like

- Enjoy fast sympathetic peer review and rapid publication of accepted articles

- Access all the published articles

Re-use any of the published material for personal use and teaching without further permission

Customer Service

If you have any further queries about your subscription, please contact our customer services team on +44 (0) 2071111105 or via email at support@bmj.com.

Visit casereports.bmj.com for more articles like this and to become a Fellow 